İsletme Bilimi Dergisi 2020

Cilt:8 Sayı:1
SAKARYA

ÜNIVERSITESI
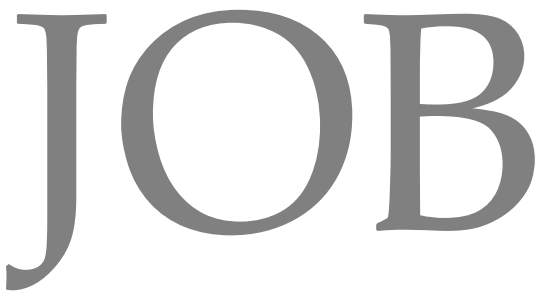

İşletme Bilimi Dergisi

The Journal of Business Science

Sakarya Üniversitesi / Sakarya University İşletme Fakültesi / Sakarya Business School

$\begin{array}{ll}\text { Cilt/Volume } & : 8 \\ \text { Say1/Issue } & : 1 \\ \text { Yil/Year } & : 2020\end{array}$

ISSN: 2148-0737

DOI: 10.22139/jobs 
İşletme Bilimi Dergisi 2020 Cilt:8 Sayı:1

ii

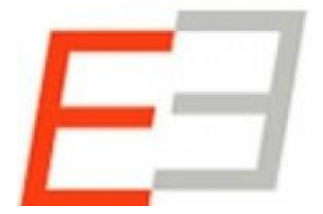

Akademilk Ansustumalari Indeksi
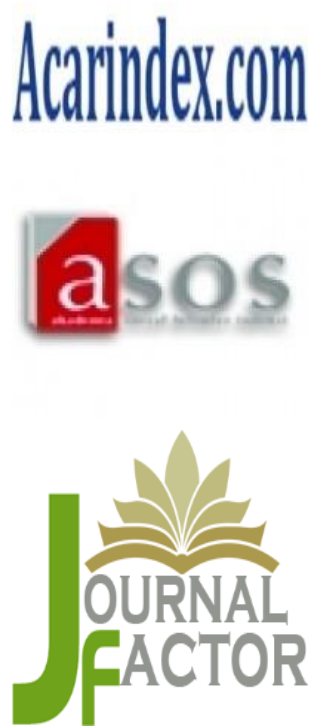
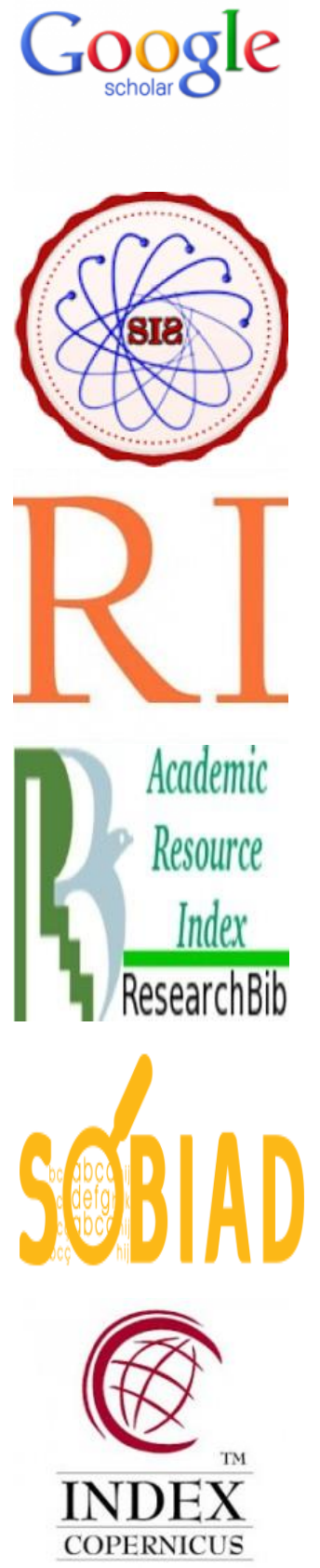
Kurucu Sahip/Founder

Issletme Bilimi Dergisi

2020

Prof. Dr. Gültekin YILDIZ

Cilt:8 Sayı:1

Imtiyaz Sahibi / Owner

Prof. Dr. Kadir ARDIÇ

Editör / Editor

Prof. Dr. Mahmut AKBOLAT

Editör Yardımcıları / Assoc. Editors

Prof. Dr. Mustafa Cahit UNGAN

Mizanpaj Editörü / Layout Editor

Arş. Gör. Dr. Özgün ÜNAL

\section{DanışmaKurulu/Advisory Board}

Prof. Dr. Ahmet Vecdi CAN

Prof. Dr. Bülent SEZEN

Prof. Dr. Dilaver TENGİLIMOĞLU

Prof. Dr. Erman COŞKUN

Prof. Dr. Kadir ARDIÇ

Prof. Dr. Mehmet BARCA

Prof. Dr. Nihat ERDOĞMUŞ

Prof. Dr. Orhan BATMAN

Prof. Dr. Recai COŞKUN

Prof. Dr. Remzi ALTUNIŞIK

Prof. Dr. Selahattin KARABINAR

Prof. Dr. Sidika KAYA

Prof. Dr. Şevki ÖZGENER

Prof. Dr. Türker BAŞ

Doç. Dr. Surendranath Rakesh JORY
Sakarya Üniversitesi

Gebze Yüksek Teknoloji Enstitüsü

Atılım Üniversitesi

İzmir Bakırçay Üniversitesi

Sakarya Üniversitesi

Ankara Sosyal Bilimler Üniversitesi

İstanbul Şehir Üniversitesi

Sakarya Üniversitesi

İzmir Bakırçay Üniversitesi

Sakarya Üniversitesi

İstanbul Üniversitesi

Hacettepe Üniversitesi

Nevşehir Üniversitesi

Galatasaray Üniversitesi

Southampton Üniversitesi 
İşletme Bilimi Dergisi

2020

Cilt:8 Sayı:1
Yayın Kurulu / Editorial Board

\author{
Prof. Dr. Kadir ARDIÇ \\ Prof. Dr. Mahmut AKBOLAT \\ Prof. Dr. Mustafa Cahid ÜNĞAN
}

Sekreterya / Secreteria

Arş. Gör. Dr. Özgün ÜNAL
Arş. Gör. Mustafa AMARAT
Arş. Gör. Ayhan DURMUŞ

Dergimize yayınlanmak üzere gönderilen makalelerin yazımında etik ilkelere uyulduğu ve yazarların ilgili etik kurulundan gerekli yasal onayları aldığı varsayılmaktadır. Bu konuda sorumluluk tamamen yazarlara aittir. İşletme Bilimi Dergisi'nde yer alan makalelerin bilimsel sorumluluğu yazara aittir. Yayınlanmış eserlerden kaynak gösterilmek suretiyle alıntı yapılabilir.

It is assumed that the articles submitted for publication in our journal are written in ethical principles and the authors have obtained the necessary legal approvals from the relevant ethics committee. The responsibility of this matter belongs to the authors. Scientific responsibility for the articles belongs to the authors themselves. Published articles could be cited in other publications provided that full referenceisgiven.

İşletme Bilimi Dergisi; www.dergipark.gov.tr/jobs SakaryaÜniversitesi İşletme Fakültesi jobs@sakarya.edu.tr Esentepe Kampüsü 54187 Serdivan/SAKARYA 


\section{Hakemler/ Reviewers}

Prof. Dr. Abdullah Naralan Prof. Dr. Ahmet Vecdi Can Prof. Dr. Adem Öğüt

Prof. Dr. Adnan Akın

Prof. Dr. Ahmet Bardakçı

Prof. Dr. Aykut Hamit Turan

Prof. Dr. Ayşe İrmiş

Prof. Dr. Bayram Şahin

Prof. Dr. Bayram Topal

Prof. Dr. Bayram Zafer Erdoğan

Prof. Dr. Dilaver Tengilimoğlu

Prof. Dr. Durmuş Acar

Prof. Dr. Ekrem Tatoğlu

Prof. Dr. Erman Coşkun

Prof. Dr. Fatih Ertaş

Prof. Dr. Gülten Gümüştekin

Prof. Dr. Halit Keskin

Prof. Dr. Hasan Tutar

Prof. Dr. Haydar Sur

Prof. Dr. Himmet Karadal

Prof. Dr. İsmet Şahin

Prof. Dr. İsmet Hakkı Eraslan

Prof. Dr. Kadir Ardıç

Prof. Dr. Kıymet Çalıyurt

Prof. Dr. Mehmet Akif Çukurçayır

Prof. Dr. Mehmet Adak

Prof. Dr. Mehmet Barca

Prof. Dr. Mehmet Sarışık

Prof. Dr. Mehmet Selami Yıldız

Prof. Dr. Muhsin Halis

Prof. Dr. Musa Özata

Prof. Dr. Mustafa Cahit Ungan

Prof. Dr. Nazan Günay

Prof. Dr. Necdet Şensoy

Prof. Dr. Nejat Bozkurt

Prof. Dr. Nilgün Sarıkaya

Prof. Dr. Nuran Cömert

Prof. Dr. Oğuz Türkay

Prof. Dr. Orhan Batman

Prof. Dr. Ömer Torlak

Prof. Dr. Özgür Uğurluoğlu

Prof. Dr. Recai Coşkun

Prof. Dr. Recep Pekdemir

Prof. Dr. Remzi Altunışık

Prof. Dr. Ruziye Cop

Prof. Dr. Selahattin Karabınar

Prof. Dr. Selman Aziz Erdem

Prof. Dr. Serap Benligiray
Recep Tayyip Erdoğan Üniversitesi

Sakarya Üniversitesi

Selçuk Üniversitesi

Kırıkkale Üniversitesi

Pamukkale Üniversitesi

Sakarya Üniversitesi

Pamukkale Üniversitesi

Hacettepe Üniversitesi

Sakarya Üniversitesi

Anadolu Üniversitesi

Gazi Üniversitesi

Süleyman Demirel Üniversitesi

Bahçeşehir Üniversitesi

İzmir Bakırçay Üniversitesi

Gaziosmanpaşa Üniversitesi

Dumlupınar Üniversitesi

Gebze Yüksek Teknoloji Enstitüsü

Eskişehir Anadolu Üniversitesi

Nişantaşı Üniversitesi

Aksaray Üniversitesi

Hacettepe Üniversitesi

Düzce Üniversitesi

Sakarya Üniversitesi

Trakya Üniversitesi

Selçuk Üniversitesi

İstanbul Üniversitesi

Yıldırım Beyazıt Üniversitesi

Sakarya Uygulamalı Bilimler Üniversitesi

Düzce Üniversitesi

Kocaeli Üniversitesi

Ahi Evran Üniversitesi

Sakarya Üniversitesi

Ege Üniversitesi

Marmara Üniversitesi

Marmara Üniversitesi

Sakarya Üniversitesi

Marmara Üniversitesi

Sakarya Uygulamalı Bilimler Üniversitesi

Sakarya Uygulamalı Bilimler Üniversitesi

Karatay Üniversitesi

Hacettepe Üniversitesi

İzmir Bakırçay Üniversitesi

İstanbul Üniversitesi

Sakarya Üniversitesi

Abant İzzet Baysal Üniversitesi

İstanbul Üniversitesi

Kocaeli Üniversitesi

Anadolu Üniversitesi
İşletme Bilimi Dergisi

2020

Cilt:8 Sayı:1 
İşletme Bilimi Dergisi

2020

Cilt:8 Sayı:1
Prof. Dr. Serap İncaz

Prof. Dr. Serdar Özkan

Prof. Dr. Şakir Sakarya

Prof. Dr. Şevki Özgener

Prof. Dr. Suayyip Calış

Prof. Dr. Sıdıka Kaya

Prof. Dr. Sima Nart

Prof. Dr. Şuayip Özdemir

Prof. Dr. Tamer Uğur

Prof. Dr. Türker Baş

Prof. Dr. Ümit Gücenme Gençoğlu

Prof. Dr. Ümmühan Aslan

Prof. Dr. Vasfi Haftacı

Prof. Dr. Yıldız Özerhan

Prof. Dr. Yusuf Çelik

Doç. Dr. Abdurrahman Benli

Doç.Dr. Adem Baltacı

Doç. Dr. Adem Sağır

Doç. Dr. Ali Taş

Doç. Dr. Aşkın Özdağoğlu

Doç. Dr. Behçet Yalın Özkara

Doç. Dr. Bora Yenihan

Doç. Dr. Bora Yıldız

Doç. Dr. Buket Bora Semiz

Doç. Dr. Burcu Adıgüzel Mercangöz

Doç. Dr. Burcu Candan

Doç. Dr. Burhanettin Zengin

Doç. Dr. Buket Bora Semiz

Doç. Dr. Cavit Yeşilyurt

Doç. Dr. Cemal Sezer

Doç. Dr. Cemal İyem

Doç. Dr. Ece Armağan

Doç. Dr. Emrah Özkul

Doç. Dr. Engin Dinç

Doç. Dr. Erdoğan Kaygın

Doç. Dr. Erkan Erdemir

Doç. Dr. Faruk Anıl Konuk

Doç. Dr. Fatih Geçti

Doç. Dr. Ferudun Kaya

Doç. Dr. Fikret Çankaya

Doç. Dr. Fuat Man

Doç. Dr. Gülfen Tuna

Doç. Dr. Hakan Murat Arslan

Doç. Dr. Hakan Tunahan

Doç. Dr. Haluk Bengü

Doç. Dr. Hasan Ayyıldız

Doç. Dr. Hasan Latif

Doç. Dr. Harun Kırılmaz
Hakemlerl Reviewers

Nişantaşı Üniversitesi

İzmir Ekonomi Üniversitesi

Balıkesir Üniversitesi

Nevşehir Üniversitesi

Sakarya Üniversitesi

Hacettepe Üniversitesi

Sakarya Üniversitesi

Afyon Kocatepe Üniversitesi

Atatürk Üniversitesi

Galatasaray Üniversitesi

Uludağ Üniversitesi

Bilecik Şeyh Edebali Üniversitesi

Kocaeli Üniversitesi

Gazi Üniversitesi

Hacettepe Üniversitesi

Sakarya Üniversitesi

İstanbul Medeniyet Üniversitesi

Karabük Üniversitesi

Sakarya Üniversitesi

Dokuz Eylül Üniversitesi

Eskişehir Osmangazi Üniversitesi

Kırklareli Üniversitesi

İstanbul Üniversitesi

Bilecik Şeyh Edebali Üniversitesi

İstanbul Üniversitesi

Kocaeli Üniversitesi

Sakarya Uygulamalı Bilimler Üniversitesi

Bilecik Şeyh Edebali Üniversitesi

Atatürk Üniversitesi

Sakarya Üniversitesi

Adnan Menderes Üniversitesi

Adnan Menderes Üniversitesi

Karadeniz Teknik Üniversitesi

Karadeniz Teknik Üniversitesi

Kafkas Üniversitesi

İstanbul Şehir Üniversitesi

Sakarya Üniversitesi

Yalova Üniversitesi

Abant İzzet Baysal Üniversitesi

Karadeniz Teknik Üniversitesi

Sakarya Üniversitesi

Sakarya Üniversitesi

Düzce Üniversitesi

Sakarya Üniversitesi

Niğde Üniversitesi

Karadeniz Teknik Üniversitesi

Sakarya Uygulamalı Bilimler Üniversitesi

Sakarya Üniversitesi 


\section{Hakemler/ Reviewers}

Doç. Dr. Hayrettin Zengin

Doç. Dr. Kazım Ozan Özer

Doç. Dr. Kemal Can Kılıç

Doç. Dr. Kubilay Özyer

Doç. Dr. Kurtuluş Kaymaz

Doç. Dr. Mahmut Hızıroğlu

Doç. Dr. Mehmet Ali Alan

Doç Dr. Mehmet Altınöz

Doç. Dr. Mehmet Saraç

Doç. Dr. Mesut Çimen

Doç. Dr. Mehmet Han Ergüven

Doç. Dr. Muammer Mesci

Doç. Dr. Musa Said Döven

Doç. Dr. Mustafa Cahid Ünğan

Doç. Dr. Mustafa Kemal Demirci

Doç. Dr. Mutlu Başaran Öztürk

Doç. Dr. Müjdat Özmen

Doç. Dr. Nevran Karaca

Doç. Dr. Nihal Sütütemiz

Doç. Dr. Niyazi Kurnaz

Doç. Dr. Oğuz Işık

Doç. Dr. Ömer Okan Fettahlıŏlu

Doç. Dr. Özlem Balaban

Doç. Dr. Ötüken Senger

Doç. Dr. Ramazan Aksoy

Doç. Dr. Recep Yilmaz

Doç. Dr. Safiye Sencer

Doç. Dr. Üyesi Samet Güner

Doç. Dr. Seçil Taştan

Doç. Dr. Sedat Bostan

Doç. Dr. Selami Özcan

Doç. Dr. Senay Yürür

Doç. Dr. Serkan Şengül

Doç. Dr. Sinan Esen

Doç. Dr. Şerife Subaşı

Doç. Dr. Şevki Ulama

Doç. Dr. Sinan Esen

Doç. Dr. Tansel Hacıhasanoğlu

Doç. Dr. Taşkın Kılıç

Doç. Dr. Tuncay Yilmaz

Doç. Dr. Umut Koç

Doç. Dr. Umut Sanem Çiftçi

Doç. Dr. Ümit Alnıaçık

Doç. Dr. Yasemin Özdemir

Doç. Dr. Yasin Şehitoğlu

Doç. Dr. Yunus Emre Öztürk

Dr. Öğr. Üyesi A. Mohammed Abubakar

Dr. Öğr. Üyesi Abit Balın
Sakarya Üniversitesi

Nişantaşı Üniversitesi

Çukurova Üniversitesi

Gaziosmanpaşa Üniversitesi

Uludağ Üniversitesi

Ankara Sosyal Bilimler Üniversitesi

Cumhuriyet Üniversitesi

Havettepe Üniversitesi

İstanbul Üniversitesi

Acıbadem Üniversitesi

Kırklareli Üniversitesi

Düzce Üniversitesi

Osmangazi Üniversitesi

Sakarya Üniversitesi

Dumlupınar Üniversitesi

Niğde Üniversitesi

Osmangazi Üniversitesi

Sakarya Üniversitesi

Sakarya Üniversitesi

Kütahya Dumlupınar Üniversitesi

Hacettepe Üniversitesi

Sütçü İmam Üniversitesi

Sakarya Üniversitesi

Kafkas Üniversitesi

Bülent Ecevit Üniversitesi

Sakarya Üniversitesi

Sakarya Üniversitesi

Sakarya Üniversitesi

Marmara Üniversitesi

Ordu Üniversitesi

Yalova Üniversitesi

Yalova Üniversitesi

Abant İzzet Baysal Üniversitesi

Sakarya Uygulamalı Bilimler Üniversitesi

Bilecik Şeyh Edebali Üniversitesi

Sakarya Uygulamalı Bilimler Üniversitesi

Sakarya Uygulamalı Bilimler Üniversitesi

Bozok Üniversitesi

Ordu Üniversitesi

Sakarya Üniversitesi

Osmangazi Üniversitesi

İzmir Bakırçay Üniversitesi

Kocaeli Üniversitesi

Sakarya Üniversitesi

Yıldız Teknik Üniversitesi

Selçuk Üniversitesi

Aksaray Üniversitesi

İstanbul Üniversitesi
İsletme Bilimi Dergisi

2020

Cilt:8 Sayı:1 


\section{Işletme Bilimi Dergisi}

2020

Cilt:8 Sayı:1

Viii

\section{Hakemler/ Reviewers}

Dr. Öğr. Üyesi Ali Özgür Karagülle

Dr. Öğr. Üyesi Adem Akbıyık

Dr. Öğr. Üyesi Ahmet Kar

Dr. Öğr. Üyesi Ahmet Yağmur Ersoy

Dr. Öğr. Üyesi Ali Coşkun

Dr. Öğr. Üyesi Ali Yılmaz

Dr. Öğr. Üyesi Algın Okursoy

Dr. Öğr. Üyesi Alper Kurnaz

Dr. Öğr. Üyesi Ayhan Serhateri

Dr. Öğr. Üyesi Aydoğan Durmuş

Dr. Öğr. Üyesi Behçet Yalın Özkara

Dr. Öğr. Üyesi Berna Eren

Dr. Öğr. Üyesi Ceren Giderler Atalay

Dr. Öğr. Üyesi Derya Ergun Özler

Dr. Öğr. Üyesi Dilek Özceylan

Dr. Öğr. Üyesi Ebru Demirci

Dr. Öğr. Üyesi Ebru Özlem Bilgin

Dr. Öğr. Üyesi Emrah Özsoy

Dr. Öğr. Üyesi Emre Oruç

Dr. Öğr. Üyesi Ersin Irk

Dr. Öğr. Üyesi Esra Dil

Dr. Öğr. Üyesi Fatma Gamze Bozkurt

Dr. Öğr. Üyesi Fatih Budak

Dr. Öğr. Üyesi Fatih Şantaş

Dr. Öğr. Üyesi Ferda Alper Ay

Dr. Öğr. Üyesi Firat Altınkaynak

Dr. Öğr. Üyesi Filiz Konuk

Dr. Öğr. Üyesi Füsun Küçükbay Gökalp

Dr. Öğr. Üyesi Gökçe Cerev

Dr. Öğr. Üyesi Gökhan GÜRLER

Dr. Öğr. Üyesi Gülcan Şantaş

Dr. Öğr. Üyesi Hacı Mehmet Yıldırım

Dr. Öğr. Üyesi Halil İbrahim Cebeci

Dr. Öğr. Üyesi İbrahim Taha Dursun

Dr. Öğr. Üyesi İrfan Usta

Dr. Öğr. Üyesi İsa Demirkol

Dr. Öğr. Üyesi İsmail Şimşir

Dr. Öğr. Üyesi Mihriban Cindiloğlu

Dr. Öğr. Üyesi Lütfi Mustafa Şen

Dr. Öğr. Üyesi Metin Bayram

Dr. Öğr. Üyesi Murat Ayanoğlu

Dr. Öğr. Üyesi Mustafa Kenan Erkan

Dr. Öğr. Üyesi Mustafa Yıldırım

Dr. Öğr. Üyesi Murat Doğdubay

Dr. Öğr. Üyesi Nermin Akyel

Dr. Öğr. Üyesi Nesrin Akca

Dr. Öğr. Üyesi Nurperihan Tosun

Dr. Öğr. Üyesi Onur Dirlik
İstanbul Üniversitesi

Sakarya Üniversitesi

Kırıkkale Üniversitesi

Sakarya Üniversitesi

Boğaziçi Üniversitesi

Kırıkkale Üniversitesi

Adnan Menderes Üniversitesi

Abant İzzet Baysal Üniversitesi

Sakarya Üniversitesi

İstinye Üniversitesi

Eskişehir Osmangazi Üniversitesi

Acıbadem Üniversitesi

Dumlupınar Üniversitesi

Dumlupınar Üniversitesi

Sakarya Üniversitesi

İstanbul Üniversitesi

Sakarya Uygulamalı Bilimler Üniversitesi

Sakarya Üniversitesi

Bilecik Şeyh Edebali Üniversitesi

Gaziosmanpaşa Üniversitesi

Sakarya Üniversitesi

Sakarya Üniversitesi

Kilis 7 Aralık Üniversitesi

Bozok Üniversitesi

Cumhuriyet Üniversitesi

Sakarya Uygulamalı Bilimler Üniversitesi

Sakarya Üniversitesi

Celal Bayar Üniversitesi

Frrat Üniversitesi

Sakarya Üniversitesi

Bozok Üniversitesi

Çanakkale Onsekiz Mart Üniversitesi

Sakarya Üniversitesi

Sakarya Üniversites

Gaziosmanpaşa Üniversitesi

Kırıkale Üniversitesi

Sakarya Uygulamalı Bilimler Üniversitesi

Hitit Üniversitesi

Sakarya Uygulamalı Bilimler Üniversitesi

Sakarya Üniversitesi

Sakarya Üniversitesi

Sakarya Üniversitesi

Sakarya Üniversitesi

Balıkesir Üniversitesi

Sakarya Uygulamalı Bilimler Üniversitesi

Kırıkkale Üniversitesi

Cumhuriyet Üniversitesi

Osmangazi Üniversitesi 


\section{Hakemler/ Reviewers}

Dr. Öğr. Üyesi Orhan Kandemir Dr. Öğr. Üyesi Osman Uslu Dr. Öğr. Üyesi Özer Uygun Dr. Öğr. Üyesi Pınar Memiş Sağır Dr. Öğr. Üyesi Sedat Durmuşkaya Dr. Öğr. Üyesi Selma Kılıç Kırılmaz Dr. Öğr. Üyesi Sema Polatçı Dr. Öğr. Üyesi Sema Yiğit Dr. Öğr. Üyesi Sema Ülkü Akpınar Dr. Öğr. Üyesi Semih Okutan Dr. Öğr. Üyesi Serkan Deniz Dr. Öğr. Üyesi Sümeyra A. Danışman Dr. Öğr. Üyesi Şevki Ulama Dr. Öğr. Üyesi Şuayyip Doğuş Demirci Dr. Öğr. Üyesi Şule Yıldız Dr. Öğr. Üyesi Tarık Semiz Dr. Öğr. Üyesi Tayfun Yılmaz Dr. Öğr. Üyesi Tuncay Turaboğlu Öğr. Gör. Dr. Aykut Yılmaz Öğr. Gör. Dr. Hüseyin İskender Öğr. Gör. Dr. İlker Calayoğlu Arş. Gör. Dr. Seda Aydan
Kastamonu Üniversitesi

Sakarya Üniversitesi

Sakarya Üniversitesi

Sakarya Üniversitesi

Sakarya Uygulamalı Bilimler Üniversitesi Sakarya Uygulamalı Bilimler Üniversitesi Gaziosmanpaşa Üniversitesi

Ordu Üniversitesi

Sakarya Üniversitesi

Sakarya Üniversitesi

Yalova Üniversitesi

Mevlana Üniversitesi

Sakarya Üniversitesi

İzmir Kâtip Çelebi Üniversitesi

Sakarya Üniversitesi

Bilecik Şeyh Edebali Üniversitesi

Mehmet Akif Ersoy Üniversitesi

Mersin Üniversitesi

Sakarya Uygulamalı Bilimler Üniversitesi

Sakarya Uygulamalı Bilimler Üniversitesi

Okan Üniversitesi

Hacettepe Üniversitesi
İşletme Bilimi Dergisi

2020

Cilt:8 Sayı:1 
İşletme Bilimi Dergisi

2020

Cilt:8 Sayı:1
Değerli Bilim İnsanları,

İşletme Bilimi Dergisinin 8. Cilt 1. Sayısını yayınlamaktan dolayı mutluluk duyuyoruz. Yedi yillık yayın hayatımızda olduğu gibi bu sayıda da farklı disiplinlerden gelen makaleler ile sizlere zengin bir içerik sunuyoruz. 8. Cilt 1. Sayımız toplam 8 makale ile yayınlanmaktadır. Yayınlanan makaleler, Sağlik Yönetim, Turizm İşletmeciliği, Muhasebe ve Finansman, Issletme Yönetimi ve Pazarlama gibi çeşitli alanlardan gelmiştir.

Sayımızın ilk makalesi Arş. Gör. Gülsüm Şeyma KOCA ve Prof. Dr. Yusuf ÇELIK tarafindan kaleme alınan "Venöz Tromboembolizmin Maliyetleri ve Ekonomik Yükünün Belirlenmesine İlişkin Sistematik Bir Derleme: Farmaekonomik Önleyici Bir Tedavi Olarak Dmah" başlıklı makaledir. Makale Venöz Thromboembolizm, Pulmoner Embolizm, Derin Ven Thrombozunun tedavi maliyetlerinin belirlenmesi ve önleyici antikoagülan bir tedavi olan Düşük Molekül A ğırlıklı Heparin bir sağlık sigortasına veya hastaneye getirdiği ekonomik yükün tespit edilmesi amaçlamaktadır. Çalışma bahsi geçen tedavi seçeneklerinin karşılaştırılması açısından ve özellikle să̆lık sigortalarının bütçesine etkisinin tahmininde büyük öneme sahiptir.

Bu sayımızın ikinci makalesi "Dolar Hegemonyası ve Kripto Para Mühendisliği Üzerine Teknolojik Risk Analizi" başlıklı makaledir. Makalenin yazarı Dr. Ahmet Efe bu çalışmada ABD Dolar senyorajının ne boyutta oluğunu tespit etmek ve bunun kripto paraların yükselişiyle etkilenip etkilenmeyeceğine ilişkin önemli paylaşımlar yapmaktadır.

Sayımızın bir diğer makalesi Öğr. Gör. Gözde UÇAR'ın kaleminden "Risk Sermayesi ve Melek Sermaye Finansman Yönteminin Girişimciliğin Finansmanı Açısından Değerlendirilmesi" başlıklı makaledir. Yazar bu çalışmada risk sermayesi ve melek sermaye finansman yöntemlerini kavram ve işleyiş bakımından incelemektir. Ayrıca, Dünya'da ve Türkiye'de girişimciler tarafindan hangi yöntemin daha fazla kullanıldı̆̆ı ya da ulaşılabilirliği açısından değerlendirmeler yaparak, yöntemlerin farklarını ve benzerliklerini ortaya koymaktadır.

Dr. Öğr. Üyesi Ali YILMAZ, Dr. Öğr. Üyesi Ahmet KAR ve Arş. Gör. Mustafa KAYA'nın kaleme aldığı "Hasta Güçlendirme ve Yaşam Kalitesi İlişkisi" başlıklı makale, hasta güçlendirme ve yaşam kalitesi arasındaki ilişkinin ve hastaların yaşam kalitesini etkileyen faktörlerin belirlenmesi amaçlamaktadır. Bu çalışma hasta güçlendirme ile yaşam kalitesi arasında ilişki olduğu ve hasta güçlendirmenin yaşam kalitesini artırdığını ortaya koyması bakımından önem arz etmektedir.

“Otel Çalışanlarının İş Tanımları Konusundaki Farkındalıkları Üzerine Bir Araştırma" başlıklı makale Oğuz TÜRKAY ve Murat EREN tarafindan kaleme alınmıştır. Makalede otel işgörenlerinin iş tanımların bilme durumlarının çok 
boyutlu bir perspektiften incelemesi amaçlanmaktadır. Çalışma sonuçları otel IKKY yetkilerinin iş tanımlarını netleştirmeleri gerektiği yönündeki bulgusuyla dikkat çekmektedir.

Sayımızın bir diğer makalesi "Kamu Hastanelerinde ve Özel Hastanelerde Yapılan Diş Çevre Analizinin Vizyon ve Misyon Oluşturma İle İlişkisi Hakkında Yönetici Görüşleri (Ankara İlinde Bir Uygulama)" başlıklı makaledir. Dr. Özlem DEMIR ve Prof. Dr. Zekai ÖZTÜRK tarafindan kaleme alınan çalışma Ankara ilinde faaliyette bulunan kamu ve özel hastanelerde yapılan dış çevre analizinin misyon ve vizyon oluşturma ile ilişkisi hakkındaki yönetici görüşlerinin belirlenmesini amaçlamaktadır.

Doç. Dr. Recep YILMAZ ve Rabia BÖLÜKBAŞI'nın hazırladıkları "Faizsiz Finansman Bonosu Sukuk Uygulaması ve Muhasebeleştirilmesi" adlı makale, bir yatırım aracı olan SUKUK"u irdeleyerek muhasebeleştirilmesine dair literatüre katkı să̆lamaktadır.

Sayımızın son makalesi Dr. Öğr. Üyesi Ayhan SERHATERİ ve Fatih Güray KURŞUN tarafindan yazılan "Deneyimsel Pazarlamanın Tüketici Satın Alma Niyeti Üzerine Etkisi: Sakarya İli Örneği" başlıklı makaledir. Makalede yazarlar deneyimsel pazarlamanın tüketici üzerindeki ve tüketicinin satın alma niyeti üzerindeki etkilerinin detaylı olarak açıklamaktadır.

Dergimiz bu sayısı da işletmeciliğin farklı disiplinlerinde değerli bilim insanlarının kıymetli çalışmalarıyla zengin bir içerik sunmaktadır. Dergi politikası olarak bundan sonraki sayılarımızda da işletme bilimine dayal farkh disiplinlerden gelen çalışmaları yayınlamaya özen göstereceğiz. Bu sayımızda göndermiş oldukları makaleler ile dergimize katkı sağlayan tüm yazarlarımıza, dergimize gönderilen makalelerin değerlendirilmesi için kıymetli vakitlerini ayıran saygıdeğer hakemlerimize ve makalelerin dergide yayınlanmaya hazır hale gelmesi için yoğun bir gayret gösteren editör kurulumuz ve dergi sekretaryamıza teşekkürlerimi sunarım. Dergimizin okurlarımı ve bilim insanlarına faydalı olması dileklerimle sonraki sayılarımızda işletmeciliğin güncel çalışmalarını bilim dünyasının hizmetine sunmak için siz değerli bilim insanları ve araştırmacıların katkıların bekliyoruz.
Işletme Bilimi Dergisi

2020

Cilt:8 Sayı:1

Saygılarımızla...

Prof. Dr. Mahmut AKBOLAT

Editör 
İşletme Bilimi Dergisi

2020

Cilt:8 Sayı:1
İÇİNDEKİLER/CONTENTS

Yil (Year) 2020 Cilt (Vol.) 8 Sayı (No) 1

\section{Derleme Makaleleri/Review Articles}

Risk Sermayesi ve Melek Sermaye Finansman Yönteminin Girişimciliğin Finansmani Açisindan Değerlendirilmesi

Evaluation of Risk Capital and Angel Capital Financing Method in Terms of Entrepreneurship

Financing

Öğr. Gör. Gözde UÇAR

Dolar Hegemonyasi Ve Kripto Para Mühendisliği Üzerine Teknolojik Risk Analizi

Technological Risk Analysis on Crypto Currency Engineering and Dollar Hegemony

Dr. Ahmet Efe

\section{Araştırma Makaleleri/Research Articles}

Venöz Tromboembolizmin Maliyetleri ve Ekonomik Yükünün Belirlenmesine Ilişkin

Sistematik Bir Derleme: Farmaekonomik Önleyici Bir Tedavi Olarak Dmah

A Systematic Review of The Determination of Costs And Economic Burden of Venous

Thromboembolism: Lmwh As A Pharmaeconomic Preventive Therapy

Arş. Gör. Gülsüm Şeyma KOCA ve Prof. Dr. Yusuf ÇELIKK

Hasta Güçlendirme ve Yaşam Kalitesi Ilişkisi

The Relationship of Patient Empowerment and Life Quality

Dr. Öğr. Üyesi Ali YILMAZ, Dr. Öğr. Üyesi Ahmet KAR ve Arş. Gör. Mustafa KAYA

Otel Çalișanlarinin Iș Tanimlari Konusundaki Farkindaliklari Üzerine Bir Araștirma

A Research on Awareness of Hotel Employees on Job Description

Ŏ̆uz TÜRKAY ve Murat EREN

Kamu Hastanelerinde ve Özel Hastanelerde Yapilan Diş Çevre Analizinin Vizyon ve Misyon Oluşturma İle İlişkisi Hakkinda Yönetici Görüşleri (Ankara İlinde Bir Uygulama) Administrative Opinionson the Relationship of External Environmental Analysis in Public and Private Hospitals on Vision and Mission Building (An Application in Ankara)

Dr. Özlem DEMIR ve Prof. Dr. Zekai ÖZTÜRK

Faizsiz Finansman Bonosu Sukuk Uygulamasi Ve Muhasebeleştirilmesi

The Application and Accounting of Interest Free Financial Bond SUKUK

Doç. Dr. Recep YILMAZ ve Rabia BÖLÜKBAŞI

Deneyimsel Pazarlamanin Tüketici Satin Alma Niyeti Üzerine Etkisi: Sakarya Ili Örneği

Effect of Experimental Marketing on Consumer Purchase Intention: Sakarya Province Case

$195-226$ Dr. Öğr. Üyesi Ayhan SERHATERİ ve Fatih Güray KURŞUN 


\title{
HASTA GÜÇLENDİRME VE YAŞAM KALİTESİ İLIŞKİSi
}

\author{
Dr. Öğr. Üyesi Ali YILMAZ \\ Kırıkkale Üniversitesi, Sağllk Bilimleri Fakültesi, Sağlık Yönetimi Bölümü \\ aliyilmaz69@gmail.com \\ ORCID ID: orcid.org/ 0000-0002-7482-1712 \\ Dr. Öğr. Üyesi Ahmet KAR \\ Kırıkkale Üniversitesi, Sağlık Bilimleri Fakültesi, Sağlık Yönetimi Bölümü \\ ahmetkar67@hotmail.com \\ ORCID ID: orcid.org/ 0000-0002-3734-497X \\ Arş. Gör. Mustafa KAYA \\ Kırıkkale Üniversitesi, Sağlık Bilimleri Fakültesi, Sağllk Yönetimi Bölümü \\ mustafa_519@hotmail.com \\ ORCID ID: orcid.org/ 0000-0002-2005-5370
}

\section{ÖZ}

Amaç: Bu çalışmada hasta güçlendirme ve yaşam kalitesi arasındaki ilişkinin ve hastaların yaşam kalitesini etkileyen faktörlerin belirlenmesi amaçlanmıştır.

Yöntem: Araştırmaya bir üniversite hastanesinde 5 Şubat-25 Mayıs 2018 tarihleri arasında dâhiliye, göğüs hastalıkları, kardiyoloji ve genel cerrahi birimlerinde poliklinik başvurusu yapan kronik hastalar dâhil edilmiştir. Astım, diyabet, kronik obstrüktif akciğer hastalığı (koah), tiroid ve kalp rahatsızlığı bulunan hastaların dâhil edildiği bu çalışmada Small (2012) tarafından geliştirilen, Kaya ve Işık (2018) tarafından Türkçe geçerlilik ve güvenilirliği yapılan hasta güçlendirme ölçeği kullanılmıştır. Hastaların yaşam kalitesi ise The Euro Qol Group tarafından geliştirilmiş olan EQ-5D 5L ölçeğinin Hollanda ağırlıkları ile uygulanması ile değerlendirilmiştir. Rastgele örnekleme yöntemi kullanılmıştır ve 515 hasta araştırmaya dâhil edilmiştir. Araştırmanın verileri SPSS 23 programı ile analiz edilmiştir.

Bulgular: Uygulanan hasta güçlendirme ölçeğine ilişkin ortalama skor 130,18 olarak gerçekleşmiştir. Hasta güçlendirme ile yaşam kalitesi arasında orta düzeye yakın pozitif yönlü bir ilişki bulunmuştur. Ayrıca yaş grubu ve kronik hastalık türünün hasta güçlendirme ve yaşam kalitesi skoru üzerinde değişikliğe yol açtığı belirlenmiştir. 
Hasta

Güçlendirme ve Yaşam Kalitesi

İlişkisi

98

Sonuç: Bu çalışmada hasta güçlendirme ile yaşam kalitesi arasında ilişki olduğu ve hasta güçlendirmenin yaşam kalitesini artırdığı sonucuna ulaşılmıştır. Bu yüzden hastaların güçlendirilmesine yönelik uygulamalara önem verilmesi, hastanın tedavisine aktif katılımının sağlanması ve uygulanacak politikaların bu doğrultuda planlanması önerilmektedir.

Anahtar Kelimeler: Kronik Hastalık, Hasta Güçlendirme, Yaşam Kalitesi.

\title{
THE RELATIONSHIP OF PATIENT EMPOWERMENT AND LIFE QUALITY
}

\begin{abstract}
Aim: In this study, it was aimed to determine the relationship between patient empowerment and life quality and the factors affecting patients' life quality.

Method: Chronic patients who applied to the internal medicine, thoracic diseases, cardiology and general surgery clinics in a university hospital between February 5 and May 25, 2018 were included in the study. In this study, which included patients with asthma, diabetes, chronic obstructive pulmonary disease (COPD), thyroid and heart disease, the patient empowerment scale developed by Small (2012) and whose Turkish validity and reliability tested by Kaya and Işık (2018) was applied. The life quality of the patients was evaluated by applying the EQ-5D 5L scale developed by The Euro Qol Group with Dutch weights. Random sampling method was used and 515 patients were included in the study. The data of the study were analyzed by SPSS 23 statistical program.

Findings: The average score of the applied patient empowerment scale was 130.18. A moderately positive relationship was found between patient empowerment and life quality. Also it was determined that age group and chronic disease type caused changes in patient empowerment and life quality score.

Results: In this study, it was concluded that there is a relationship between patient empowerment and life quality and patient empowerment increases the life quality. Therefore, it is recommended to attach importance to practices for empowering patients, to ensure active participation in the treatment of the patient and to plan the policies to be implemented accordingly.
\end{abstract}

Key Words: Chronic Illness, Patient Empowerment, Life Quality

\section{I.GİRIŞ}

Günümüzde ülkeler sağlık hizmetleri sunumunda yaşlanan nüfus, kronik hastalıkların artması, finansal kaynakların yetersizliği, hasta güvenliği gibi problemler yaşamaktadır. Bu durum hizmeti kullananlarda memnuniyetsizliklere yol açmakta ve ülkelere çok önemli yükler 
getirmektedir. Sağlık hizmetlerinin sürdürebilirliğini sağlamak için gerekli olan önleyici, tedavi edici hizmetlerin sunumu, araştırma faaliyetleri ve güncel teknoloji kullanımı için çok daha fazla finansal kaynağa ihtiyaç duyulmaktadır. Ülkelerin içinde bulunduğu finansal zorluklar, ülkeleri kaynak yaratmada farklı stratejiler geliştirmeye yöneltmiştir. Geçmişte, sağlık kuruluşlarında, etkinlik ve verimlilik konusundaki iyileştirmelere

odaklanılmışken, son yillarda hastanın sağlık hizmetlerinin sürdürülebilirliğinde temel bir kaynak olarak değerlendirilmesine ve aktif rolü üzerinde durulmaktadır (Russo et al., 2019). Dünya Sağlık Örgütü 2020 sağlık hedefleri arasında; sağlık hizmetlerinin sonuçlarını, sağlık sistemi performansını ve sağlık hizmetlerinden memnuniyeti iyileştirmek için hasta merkezli bir sağlık hizmeti ve hasta güçlendirmenin önemini vurgulamaktadır (WHO, 2013: 118).

Sağlık hizmetlerinin değerlendirilmesi, ağırlıklı olarak sağlık sonuçlarının ölçülmesine dayanmaktadır. Sağlık değerlendirmesinde son dönemlerde psiko-sosyal, güçlendirme gibi sağlıkla doğrudan ilgili olmayan çıktılar üzerinde değerlendirmeler yapılmaktadır. Sağlık durumunun psikososyal sonuçlardan ayrılması düşüncesi ilk kez 1988'de Kleinman tarafından kronik hastalıkların yönetiminde savunulmuştur. $O$ zamandan beri, hastanın güçlenmesi sağlık hizmetlerinde güvenilir bir uygulama haline gelmiş ve paternalist modellerden uzaklaşılarak, klinisyen-hasta işbirliğine dayanan, hastanın bilgilendirilerek karar süreçlerine dâhil edildiği ve sürecin birlikte yönetildiği güçlendirilmiş hastaya doğru bir değişim yaşanmıştır (Barr et al., 2015: 2; McAllister et al., 2012).

Hastanın güçlendirilmesinde önemli katkıları olan sağlıklı yaşam biçimi davranışları ve sağlık okuryazarlığı gibi alanlarda, davranış değişikliğini tanımlama ve sağlık sonuçlarının ölçümüne odaklanılmaktadır. İlk yapılan çalışmalar bireysel öz yeterlik, tutumlar, inançlar, öznel normlar gibi psikolojik yaklaşımlara odaklanırken, daha sonra yapılan çalışmalarda bilişsel yönelimler benimsenmiş bilgi, okuryazarlık ve bireysel beceriler gibi kavramlara yönelim olmuştur. Hastanın davranışlarını ve sağlığını açıklayan bilişsel ve psikolojik yaklaşım Schulz ve Nakamoto (2011) tarafından birleştirilerek yeni bir model geliştirilmiştir. Bu model sağlık bilgisi, güçlendirme, davranış ve sağlık sonuçlarını birlikte değerlendirmeyi önermektedir. Hastanın davranışındaki farklılıkları açıklamada kişisel bilgi ve güçlendirmenin etkisinin önemli olduğu savunulmaktadır. Sağlı̆̆ın güçlendirilmesi, bireysel güç ve yetkinlikler arasında bir bağlantı sağlayan, sosyal politikalara ve sosyal değişime katkı sağlayan proaktif bir doğal sistemdir. Perkins ve Zimmerman (1995)'a göre güçlendirme, özgüven, öz yeterlik, yetkinlik, kontrol odağı gibi geleneksel psikolojik yapıların 
İşletme Bilimi Dergisi (JOBS), 2020; 8(1): 97-114. DOI: 10.22139/jobs.682555

\section{Hasta}

Güçlendirme ve Yaşam Kalitesi İlişkisi

100 ötesinde, kendi kaderini tayin etmeyle yakından bağlantılı çok düzeyli ve çok boyutlu bir yapıdır. Bireylerin bilgilendirilerek gönüllü olarak bu sürece katılması son derece önemlidir (Camerini et al., 2012: 337-344). Hastanın karar alma aşamasında bilgilendirilerek kararlara hazırlanması ve karar vermede fiili katılımın sağlanması olumlu sonuçlar doğurmaktadır (Alden, 2014: 884). Hasta güçlendirme; hastanın eğitimi, tedavide sorumluluk üstlenmesi ve sağlık hizmetlerini yönetmede aktif katılımının sağlanması olarak da tanımlanmaktadır. Hasta güçlendirme, hastanın sağlık okuryazarlığının, kontrol, katılım ve iletişim becerilerinin geliştirilmesiyle sağlanabilmektedir (Russo vd, 2019: 1315).

Bireysel düzeyde yetkilendirme, kişinin kimliğini ve özgüvenini yeniden keşfettiği ve "hayatını kendi eline aldığı" süreçlerle ilgilidir (Delespaul et al., 2016). Hastanın güçlendirilmesi, hastaların bilgi, beceri ve ihtiyaçlar konusunda farkındalık geliştirmelerine yardımcı olacak bir süreçtir. Bu süreç, hastaların amaçlarını tanımlamalarına, tıbbi tedavilerinin sorumluluğunu almalarına ve özerkliklerini artırmalarına katkıda bulunur. Bunun sonucunda problem çözme yetenekleri gelişir, sağllk profesyonelleriyle sağlıklı iletişim kurabilirler ve sağlığı geliştirici faaliyetlerde bulunurlar (Feste ve Anderson, 1995).

Özellikle de artık yaşamlarının bir parçası haline gelmiş kronik bir hastalığa sahip bireylerin güçlendirilmesi, güçlendirmenin yaşam kalitesi üzerindeki etkilerinden ötürü ayrıca önem arz etmektedir. Sağlıkla ilgili yaşam kalitesi fiziksel, fizyolojik ve sosyal işlevsellik olmak üzere en az üç genel alanı içeren çok boyutlu bir yapıdır. Bu yapı, deneyimi yaşayanların bakış açısıyla bilişsel faktörlerin aracılık ettiği objektif ve sübjektif alt boyutları barındırmaktadır. Sağlıkla ilgili yaşam kalitesi hastalık, sakatlık, tedavi ya da politikalardan etkilenen eksiklikler, fonksiyonel durumlar, algılar veya sosyal fırsatların düzenlemiş olduğu yaşam sürecine atanmış değeri ifade etmektedir (Megari, 2013). Wilson ve Cleary (1995) tarafından geliştirilen sağlıkla ilişkili yaşam kalitesi kavramsal konseptine göre fizyolojik değişkenler semptomlara kaynaklık etmekte, semptomlar da fonksiyonel sağlık aracılığıyla genel sağlık algısını, dolayısıyla sağlıkla ilişkili genel yaşam kalitesini etkilemektedir. Kronik hastalıkların yaygınlaşması ve getirdiği yükün artmasıyla birlikte kronik hastalıklarda yaşam kalitesinin ve belirleyici faktörlerinin sıklıkla değerlendirildiği görülmektedir. 


\section{YÖNTEM}

Hasta

Bu çalışmada hasta güçlendirme ve yaşam kalitesi arasındaki ilişkiyi incelemek ve hastaların yaşam kalitesini etkileyen faktörleri değerlendirmek amaçlanmaktadır. 2018 yılı sağlık istatistikleri yıllığına göre Türkiye' de tüm ölüm nedenleri arasında bulaşıcı olmayan hastalıkların payı \%87,5'tir. Bu hastalıkların içerisinde ise habis urlardan sonra ilk üç sırada dolaşım sistemi hastalıkları, kronik alt solunum yolu hastalıkları ve diyabet tiroid gelmektedir. Yürütülen bu çalışmada bu ana tanıları temsilen astım, diyabet, koah, tiroid ve kalp rahatsızlığı olan hastalara bu hastalığa sahip bireylerin en sık başvuracağı poliklinikler olan dahiliye, göğüs hastalıkları, kardiyoloji ve genel cerrahi birimlerinde ulaşılmaya çalışılmıştır. Çalışma kapsamına bir üniversite hastanesinde 5 Şubat-25 Mayıs 2018 tarihleri arasında söz konusu polikliniklere başvuran ilgili hastalığa sahip kişiler dahil edilmiştir. Veri toplama aracı olarak Small (2012) tarafından geliştirilen, Kaya ve Işık (2018) tarafından Türkçe geçerlilik ve güvenilirliği yapılan hasta güçlendirme ölçeği kullanılmıştır. Orijinalinde 47 sorudan oluşan ölçek Kaya ve Işık (2018) tarafından yürütülen doğrulayıcı faktör analizi neticesinde uyum iyiliği kabul edilebilir düzeyde olan 37 ifadeye indirgenmiştir. Bu çalışmada da 37 ifadeden oluşan ölçek kullanılmıştır. Hastaların yaşam kalitesi ise The Euro Qol Group tarafından geliştirilmiş olan EQ-5D 5L ölçeğinin Hollanda ağırlıkları ile uygulanması ile değerlendirilmiştir. Rastgele örneklem seçiminin uygulandığı bu çalışmada hastaların tanımlayıcı özellikleri araştırmacılar tarafından hazırlanan form aracılığı ile temin edilmiştir. Toplamda 515 hastadan kullanılabilir anket formu elde edilmiştir.

Kullanılan veri setinin normal dağılıma uygunluk gösterip göstermediği çarpıklık ve basıklık katsayıları aracılığıyla kontrol edilmiş ve bu değerlerin \pm 2 aralığında kaldığı görülmüştür. Bu nedenle normal dağılım gösteren veri seti için parametrik testler tercih edilmiştir. Çalışma kapsamında hasta güçlendirme ve yaşam kalitesi arasındaki ilişki Pearson korelasyon analizi ile incelenmiştir. Hasta güçlendirme ve yaşam kalitesi skorlarının yaş grupları ve kronik hastalık türü açısından değerlendirmesi Çift Yönlü Manova analizi ile yapılırken cinsiyet açısından değerlendirme Independent Sample $\mathrm{T}$ testi ile gerçekleştirilmiştir. Hastaların yaşam kalitesini etkileyen faktörlerin değerlendirmesi için doğrusal regresyon analizi uygulanmıştır. 
İşletme Bilimi Dergisi (JOBS), 2020; 8(1): 97-114. DOI: 10.22139/jobs. 682555

\section{Hasta}

Güçlendirme ve Yaşam Kalitesi

İlişkisi

102

\section{BULGULAR}

Çalışmaya dahil edilen bireylerin yaş, cinsiyet ve sahip olduğu kronik rahatsızlık türünü tanımlayan istatistikler Tablo 1'de gösterilmektedir.

Tablo 1.

Hastaların tanımlayıcı özellikleri

\begin{tabular}{lccc}
\hline & Yaş & Sayı & $\%$ \\
\hline 30 ve altı & 69 & 13,4 \\
$31-50$ & 147 & 28,5 \\
$51-70$ & 243 & 47,2 \\
$71-90$ & 56 & 10,9 \\
\hline & Cinsiyet & Sayı & $\%$ \\
\hline Kadın & 332 & 64,5 \\
Erkek & Kronik Hastalık Türü & 183 & 35,5 \\
\hline & Sayı & $\%$ \\
\hline Astım & 112 & 21,7 \\
Diyabet & 152 & 29,5 \\
KOAH & 66 & 12,8 \\
Tiroid & 99 & 19,2 \\
Kalp & 86 & 16,7 \\
\hline
\end{tabular}

Çalışma kapsamında değerlendirilen hastaların büyük çoğunluğu kadınlardan oluşmaktadır. Yaş gruplarına göre dağılım incelendiğinde ise yarıya yakın bir yoğunluğun 51-70 yaş aralığında toplandığı görülmektedir. Diyabet ve astım hastalıkları bu hastalar arasında yoğunluğun en fazla olduğu kronik hastalık türleridir.

Tablo 2.

Hasta güçlendirme ölçeğine ve alt boyutlarına ilişkin değerler

\begin{tabular}{lcccc}
\hline & Minimum & Maksimum & Ortalama & $\begin{array}{c}\text { Standart } \\
\text { sapma }\end{array}$ \\
\hline Güçlendirme genel toplam & 56,00 & 185 & 130,18 & 25,85 \\
Kimlik özdeşleştirme & 1,13 & 5,00 & 3,55 & 0,88 \\
Kişisel kontrol & 1,43 & 5,00 & 3,47 & 0,78 \\
Karar alma & 1,50 & 5,00 & 3,60 & 0,83 \\
Bilme ve anlama & 1,50 & 5,00 & 3,38 & 0,77 \\
Başkaları ile etkileşim & 1,00 & 5,00 & 3,60 & 0,98 \\
\hline
\end{tabular}

Toplamda en düşük 37 en yüksek 185 puana sahip olunabilen hasta güçlendirme ölçeğinin uygulandığ 185skoru hesaplanmıştır. Ölçeğin uygulandığı hastaların ortalama skoru ise 130,18 olarak gerçekleşmiştir. Ölçeğin alt boyut ortalamaları incelendiğinde en yüksek ortalamaya başkaları ile etkileşim ve karar alma boyutunun; en 
düşük ortalamaya ise bilme ve anlama boyutunun sahip olduğu Hasta görülmektedir. Tablo 2'deki hasta güçlendirmenin alt boyutlarına ilişkin minimum ve maksimum değerler o boyutu oluşturan ifadelere 1-5 aralığında verilen yanıtların ortalaması alınarak hesaplanmıştır. Tablodaki değerler bu ortalamalar içerisindeki minimum ve maksimum değerler ile bunların ortalamasını ifade etmektedir.

Tablo 3.

Hasta güçlendirme ve yaşam kalitesi arasındaki ilişki

\begin{tabular}{lcc}
\hline Pearson Correlation & QALY & Güçlendirme \\
\hline QALY & 1 & 0,417 \\
Güçlendirme & 0,417 & 1 \\
\hline$=0,000$ (Sig. 0,01) & &
\end{tabular}

Hasta güçlendirme ve yaşam kalitesi arasında orta düzeye yakın pozitif yönlü bir ilişki bulunmuştur.

Tablo 4.

Cinsiyete göre hasta güçlendirme ve yaşam kalitesi

\begin{tabular}{lcccccccccc}
\hline & \multicolumn{4}{c}{ Yaşam Kalitesi } & \multicolumn{5}{c}{ Hasta Güçlendirme } \\
\cline { 2 - 10 } Cinsiyet & Ort. & $\begin{array}{c}\text { Std. } \\
\text { sapma }\end{array}$ & $\mathrm{t}$ & $\mathrm{df}$ & $\begin{array}{c}\text { Sig.(2- } \\
\text { tailed) }\end{array}$ & Ort. & $\begin{array}{c}\text { Std. } \\
\text { sapma }\end{array}$ & $\mathrm{t}$ & $\mathrm{df}$ & $\begin{array}{c}\text { Sig.(2- } \\
\text { tailed) }\end{array}$ \\
\hline Kadin & 0,61 & 0,29 & $-1,45$ & 513 & 0,147 & 3,55 & 0,72 & 0,913 & 488 & 0,362 \\
Erkek & 0,65 & 0,27 & & & & 3,49 & 0,68 & & & \\
\hline
\end{tabular}

Ort. $=$ Ortalama, Std. $=$ Standart .

Yaşam kalitesi ve hasta güçlendirme skorlarının cinsiyet açısından anlamlı bir farklılık gösterip göstermediği T-testi analizi ile incelenmiştir. Analiz sonucu elde edilen bulgura göre istatistiksel olarak cinsiyet değişkeni yaşam kalitesi ve hasta güçlendirme skoru açısından anlamlı bir farklılık yaratmamaktadır. Hasta güçlendirmenin alt boyutları açısından yapılan analizlerde de cinsiyet değişkeninin herhangi bir alt boyut ortalamasında anlamlı bir farklılık yaratmadığı görülmüştür. 


\section{Hasta}

\section{Güçlendirme ve} Yaşam Kalitesi

İlişkisi

104
Tablo 5.

Kronik hastalık türü ve yaş grupları açısından hasta güçlendirme ve yaşam kalitesi skorlarının değerlendirilmesi

\begin{tabular}{|c|c|c|c|c|c|c|c|}
\hline & $\begin{array}{c}\text { Bağımlı } \\
\text { Değişken }\end{array}$ & $\begin{array}{c}\text { Kareler } \\
\text { Toplamı }\end{array}$ & $\begin{array}{c}\text { Serbestlik } \\
\text { Derecesi }\end{array}$ & $\begin{array}{c}\text { Kareler } \\
\text { Ortalaması }\end{array}$ & $\mathbf{F}$ & $\mathbf{P}$ & $\begin{array}{c}\text { Kismi } \\
\text { Eta } \\
\text { Kare } \\
\end{array}$ \\
\hline \multirow[t]{2}{*}{$\begin{array}{l}\text { Düzeltilmiş } \\
\text { model }\end{array}$} & $\begin{array}{l}\text { Hasta } \\
\text { güçlendirme }\end{array}$ & 35957,653 & 19 & 1892,508 & 3,132 & ,000 & ,107 \\
\hline & $\begin{array}{l}\text { Yaşam } \\
\text { kalitesi }\end{array}$ & 6,846 & 19 & ,360 & 5,521 & ,000 & ,175 \\
\hline \multirow[t]{2}{*}{ Intercept } & $\begin{array}{l}\text { Hasta } \\
\text { güçlendirme }\end{array}$ & 2798475,505 & 1 & 2798475,505 & 4631,016 & ,000 & ,903 \\
\hline & $\begin{array}{l}\text { Yaşam } \\
\text { kalitesi }\end{array}$ & 64,577 & 1 & 64,577 & 989,480 & ,000 & ,667 \\
\hline \multirow{2}{*}{$\begin{array}{l}\text { Kronik } \\
\text { hastalık } \\
\text { türü }\end{array}$} & $\begin{array}{l}\text { Hasta } \\
\text { güçlendirme }\end{array}$ & 7275,939 & 4 & 1818,985 & 2,830 &, 024 & ,022 \\
\hline & $\begin{array}{l}\text { Yaşam } \\
\text { kalitesi }\end{array}$ & 1,404 & 4 & ,351 & 4,743 & ,001 & ,036 \\
\hline \multirow[t]{2}{*}{ Yaş grupları } & $\begin{array}{l}\text { Hasta } \\
\text { güçlendirme }\end{array}$ & 16744,450 & 3 & 5581,483 & 9,236 & ,000 &, 053 \\
\hline & $\begin{array}{l}\text { Yaşam } \\
\text { kalitesi }\end{array}$ & 3,616 & 3 & 1,205 & 18,466 & ,000 & 101 \\
\hline \multirow{2}{*}{$\begin{array}{l}\text { Kronik } \\
\text { hastalık*yaş } \\
\text { grupları }\end{array}$} & $\begin{array}{l}\text { Hasta } \\
\text { güçlendirme }\end{array}$ & 9662,095 & 12 & 805,175 & 1,332 & ,196 & ,031 \\
\hline & $\begin{array}{l}\text { Yaşam } \\
\text { kalitesi }\end{array}$ & ,497 & 12 & ,041 & 635 & 813 & ,015 \\
\hline \multirow[t]{2}{*}{ Hata } & $\begin{array}{l}\text { Hasta } \\
\text { güçlendirme }\end{array}$ & 299123,411 & 495 & 604,290 & & & \\
\hline & $\begin{array}{l}\text { Yaşam } \\
\text { kalitesi }\end{array}$ & 32,306 & 495 & ,065 & & & \\
\hline \multirow[t]{2}{*}{ Toplam } & $\begin{array}{l}\text { Hasta } \\
\text { güçlendirme }\end{array}$ & 9124323,242 & 515 & & & & \\
\hline & $\begin{array}{l}\text { Yaşam } \\
\text { kalitesi }\end{array}$ & 242,494 & 515 & & & & \\
\hline \multirow[t]{2}{*}{$\begin{array}{l}\text { Düzeltilmiş } \\
\text { Toplam }\end{array}$} & $\begin{array}{l}\text { Hasta } \\
\text { güçlendirme }\end{array}$ & 335081,063 & 514 & & & & \\
\hline & $\begin{array}{l}\text { Yaşam } \\
\text { kalitesi }\end{array}$ & 39,152 & 514 & & & & \\
\hline
\end{tabular}

Yürütülen çift yönlü manova analizinde Box's test ile kovaryans matrislerinin eşitliği $(p>0,05)$ doğrulanmıştır. Analiz neticesinde elde edilen bulgulara göre hastaların sahip olduğu kronik hastalık türü ve yaş grupları, hasta güçlendirme ve yaşam kalitesi skorları üzerinde istatistiki olarak anlamlı farklılık yaratmaktadır. Bu farklılığın hangi alt gruplardan kaynaklandığını belirlemek amacıyla Bonferroni ve Tamhane post hoc testlerine başvurulmuştur. Dört yaş grubu arasında da yaşam kalitesi ortalamaları açısından anlamlı farklılık tespit edilmiştir. Yaş grupları hasta güçlendirme açısından incelendiğinde ise 30 ve altı yaş grubu ile 31-50 yaş 
grubu arasında, 51-70 yaş grubu ile de 71-90 yaş grubu arasında fark olmadığı, diğer yaş grupları arasında anlamlı farklılık olduğu bulunmuştur.

Hastalık türleri açısından güçlendirme skorunda farklılığın hangi gruplardan kaynaklandığına bakıldığında farklılığın Tiroid ve $\mathrm{KOAH}$ grupları arasında oluştuğu tespit edilmiştir. Yaşam kalitesi açısından ise

Hasta farklılığın hem Tiroid ve KOAH hastaları arasında hem de Diyabet ve KOAH hastaları arasında olduğu görülmüştür.

Tablo 6.

Hasta güçlendirme, yaş ve cinsiyet değişkenlerinin yaşam kalitesi üzerine etkisi

\begin{tabular}{|c|c|c|c|c|c|c|c|}
\hline & \multicolumn{2}{|c|}{$\begin{array}{c}\text { Std. } \\
\text { katsayılar }\end{array}$} & \multirow{2}{*}{$\begin{array}{c}\begin{array}{c}\text { Std. } \\
\text { katsayılar }\end{array} \\
\beta\end{array}$} & \multirow[t]{2}{*}{$t$} & \multirow[t]{2}{*}{ Sig } & \multirow[t]{2}{*}{ Tolerans } & \multirow[t]{2}{*}{ VIF } \\
\hline & B & $\begin{array}{l}\text { Standart } \\
\text { hata }\end{array}$ & & & & & \\
\hline $\begin{array}{l}\text { Hasta } \\
\text { güçlendirme }\end{array}$ & 0,004 & 0,000 & ,340 & 8,547 & 0,000 & 0,924 & 1,082 \\
\hline Cinsiyet & 0,051 & 0,022 & ,088 & 2,305 & 0,022 & 0,998 & 1,002 \\
\hline Yaş & $-0,005$ & 0,001 & $-0,287$ & $-7,218$ & 0,000 & 0,924 & 1,083 \\
\hline $\begin{array}{l}R=0,505 \\
\text { Std. }=\text { Standa } 1\end{array}$ & \multicolumn{2}{|c|}{$R^{2}=0,255$} & Düzeltilmiş $R$ & $=0,251$ & Durbin & Watson= & 1,592 \\
\hline
\end{tabular}

Çalışma kapsamında yaşam kalitesine etki edebilecek değişkenlerin tahmini için çoklu doğrusal regresyon analizinden yararlanılmıştır. Modele dahil edilen değişkenler arasında sorun teşkil edecek bir çoklu korelasyon bulunmamaktadır (VIF $<10$ ve Tolerans $>0,2)$. Hasta güçlendirme, cinsiyet ve yaş değişkenlerinin yaşam kalitesi üzerinde anlamlı etkisi bulunmaktadır. $\mathrm{Bu}$ üç değişken birlikte yaşam kalitesindeki değişimin \% 25’lik kısmını açıklayabilmektedir. Standartlaştırılmış regresyon katsayılarına göre incelenen değişkenlerin yaşam kalitesi üzerindeki göreli önem sırası hasta güçlendirme $(\beta=0,340)$, yaş $(\beta=-0,287)$ ve cinsiyet $(\beta=0,088)$ şeklinde gerçekleşmiştir.

\section{TARTIŞMA VE SONUÇ}

Güçlendirme, insanların davranışlarını değiştirmelerine ve sağlıklarına ilişkin kararlar almalarına yardımcı olan bir vizyondur. Yaşam kalitesini etkileyen bir müdahale, teknik veya stratejiden daha fazlasını ifade etmektedir (Tol et al., 2015). Sağlık hizmetlerinin sunum süreçlerinde yaşanan değişimler zaman içerisinde hizmet sunan ve alanların rollerinde 


\section{Hasta}

Güçlendirme ve Yaşam Kalitesi

İlişkisi

106

ve bu rolleri yerine getirme biçimlerinde farklılıklar yaratmıştır. Hasta güçlendirme kavramı ortaya çıkan bu değişimlerin sonuçlarından birisidir. Kronik hastalıkların yükünün artması, yaşlanma, terminal dönem bakımı, daha sağlıklı yaşam biçimlerinin teşvik edilmesi ihtiyacı ve kompleks durumlara sahip insanların bakımının koordine edilmesindeki zorluklar hasta güçlendirmenin önem ve gerekliliğini gün yüzüne çıkarmıştır (All Party Parliamentary Groups on Global Health, 2014).

Bu çalışmada kronik hastalığı olan bireylerde hasta güçlendirme ve yaşam kalitesi arasındaki ilişkiyi incelemek ve yaşam kalitesi üzerinde etkili olan faktörleri belirlemek amaçlanmıştır. Araştırmaya dâhil edilen hastalar hasta güçlendirme ölçeğinden 130,18 ortalama skor elde etmişlerdir. Hastalar ölçeğin alt boyutlarından en yüksek ortalama skoru başkaları ile etkileşim ve karar alma boyutlarından elde ederken, en düşük ortalama skoru ise bilme ve anlama boyutundan elde etmişlerdir. Hastaların başkalarıyla etkileşim boyutundan aldıkları yüksek puan benzer durumdaki diğer hastaların hastalıklarıyla başa çıkmalarına yardımcı olmaya çalıştıklarını gösterirken, karar alma boyutundan elde ettikleri yüksek puan tedavi ile kararlara aktif katıldıkları ve gerekli durumlarda tedavi seçeneklerini değiştirebilecekleri konularında diğer boyutlara göre daha yetkin olduklarını göstermiştir. Karar alma ve başkaları ile etkileşim yetkinlikleri yüksek olsa bile bilme ve anlama boyutundan aldıkları düşük skor ortalaması yanlış karar alabileceklerini ve bu yanlış kararlar ile başkalarının davranışlarını yanlış yönlendirebileceklerini göstermektedir.

Çalışma kapsamında yaş gruplarının yaşam kalitesi ve hasta güçlendirme skorları üzerinde fark oluşturduğu görülmüştür. Yaş gruplarına göre en yüksek yaşam kalitesi ve hasta güçlendirme skoru en genç grupta ortaya çıkmıştır. Yaş arttıkça hem yaşam kalitesi hem de hasta güçlendirme skorlarında düşüş olduğu gözlemlenmiştir. Yaş grupları ile yaşam kalitesi ve hasta güçlendirme skoru ortalamalarının farklılık gösterip göstermediği incelemesi sonucunda gruplar arasında anlamlı farklılık tespit edilmiştir. Yaşın yaşam kalitesini etkileyen faktörlerden biri olduğunu belirten Boylu ve Paçacıŏlu (2016) 65 ve üzerinde yaşa sahip kişilerde sağlığın kötü algılanması veya herhangi bir kronik hastalığa sahip olunmasının yaşam kalitesini olumsuz etkilediğini belirtmiştir. Bu sonucun araştırmaya dâhil edilen hasta grubunun kronik hastalığa sahip olan hastalar olmasından dolayı belli bir yaş üstünde olmaları ve eğitim seviyelerinin düşük olmasından kaynaklanabileceği düşünülmektedir. Ayrıca tedavi geçmişlerinin büyük çoğunlukta 2 yıl ve altında olmasından ötürü hastaların hastalıklarıyla ilgili yetersiz bilgiye sahip olması da bu sonucu etkilemiş olabilir. Hastaların yaşlı olmasının sağlık 
okuryazarlıklarının da düşük olmasına dolayısıyla hastalıklarını kendi başlarına yönetememelerine ve yaşam kalitesinde düşüşe neden olduğu düşünülmektedir. Çimen ve Temel (2017) yaş değişkeninin sağlık okuryazarlığının istatistiksel olarak anlamlı bir yordayıcısı olduğunu ifade etmiş, yaşlı bireylerde sağlık okuryazarlığının daha düşük olduğunu belirtmiştir.

Hasta

Güçlendirme ve

Yaşam Kalitesi

İlişkisi

$\mathrm{Bu}$ çalışmada hasta güçlendirme ve yaşam kalitesi skorlarının cinsiyete göre farklılık göstermediği sonucuna ulaşılmıştır. Hasta güçlendirme ölçeğinin alt boyutlarında da benzer sonuç elde edilmiştir. Small ve arkadaşları (2013) yaptıkları çalışmada benzer şekilde cinsiyet ile hasta güçlendirme arasında anlamlı bir ilişki olmadığı sonucuna ulaşmışlardır. Kronik hastalığın türüne göre hasta güçlendirme ve yaşam kalitesi skor ortalamaları arasında ise anlamlı farklılıklar olduğu bulunmuştur. Yaşam kalitesi en yüksek olan hastalık grubu tiroid olurken en düşük grubu KOAH hastaları oluşturmaktadır. Hasta güçlendirme ile kronik hastalıklar arasında da yaşam kalitesi ile aynı sonuçlar elde edilmiştir. Hasta güçlendirme skorunda en yüksek ortalamaya tiroid hastaları, en düşük ortalamaya ise $\mathrm{KOAH}$ hastaları sahiptir. Hasta güçlendirmede farkı oluşturan gruplar tiroid ve $\mathrm{KOAH}$ iken, yaşam kalitesinde ise $\mathrm{KOAH}$ ve diyabet hastalarıdır. $\mathrm{KOAH}$ dünya genelinde prevelansı yüksek olan ve insanların yaşam kalitesini etkileyen hastalıklardan biridir (Tabari et.al., 2018). Bu yüzden hasta güçlendirme ve yaşam kalitesi skor ortalamalarının düşük olması beklenen sonuçlardandır. $\mathrm{Bu}$ sonuç aynı zamanda güçlendirilmeye en çok ihtiyacı olan hastaların KOAH'a sahip hastalar olduğu sonucunu göstermektedir. Soyyiğit ve arkadaşları (2006) KOAH hastalarında yaşam kalitesini SF-36 testi ile değerlendirmiş, bu hastaların yürüme mesafelerinin normalden düşük olduğunu, ölçeğin ağrı boyutu dişındaki tüm alt boyutlarının normalden daha düşük skora sahip olduğunu, hastalığın ilerlemesi ile genel sağlık, fiziksel ve sosyal fonksiyonların düşüş gösterdiğini belirtmiştir.

Hasta güçlendirme ile yaşam kalitesi arasındaki ilişkiyi incelemek için yapılan korelasyon analizinde modele dahil edilen değişkenler arasında sorun teşkil edecek bir çoklu korelasyon bulunmadığı ve aralarında orta düzeye yakın pozitif yönlü bir ilişki olduğu görülmüştür $(r=0,417, p<0,001)$. Oluşturulan regresyon modelinde hasta güçlendirme, cinsiyet ve yaş değişkenlerinin yaşam kalitesi üzerinde anlamlı bir etkisinin olduğu, bu üç değişken birlikte yaşam kalitesindeki değişimin \%25'lik kısmını açıklayabildiği sonucuna ulaşılmıştır $(R=0,505$; $R 2=0,255$; Düzeltilmiş $R 2=$ 0,25 ; Durbin Watson=1,592). Yaşam kalitesi üzerindeki bu etkide önem sirası hasta güçlendirme $(\beta=0,340)$, yaş $(\beta=-0,287)$ ve cinsiyet $(\beta=0,088)$ şeklindir.. 


\section{Hasta}

Güçlendirme ve Yaşam Kalitesi

İlişkisi

108
Tabari ve arkadaşları (2018) KOAH'a sahip bireyler üzerinde yaptığ1 çalışmada aile merkezli güçlendirmenin yaşam kalitesini artırdığı sonucuna ulaşmıştır. Teymori ve arkadaşları (2017) astımlı hastalar üzerinde yaptığ çalışma sonuçlarına göre güçlendirme ve hastalıkla baş edebilme öz yeterlilik arasında anlamlı bir ilişki olduğunu, güçlendirmenin öz yeterliliği artırdığını belirtmişlerdir. Raheb ve arkadaşları (2018) bir diyaliz merkezinde hizmet alan hastalar üzerinde yaptıkları çalışmada hastalara güçlendirme eğitimi vermiş, eğitim öncesi ve sonrası hastaların yaşam kalitesinde anlamlı bir atış gözlendiği sonucuna varmıştır. Náfrádi ve arkadaşları (2018) yaptıkları çalışmada inceledikleri 10 hasta grubunun 9'unda hasta güçlendirmenin yaşam kalitesi üzerinde etkili olduğunu, sağlık okuryazarlık ve güçlendirme seviyesi yüksek olan hastaların sağlık durumlarının daha iyi olduğu sonucuna ulaşmıştır. Forlani ve arkadaşları (2006) güçlendirmeyle hastaların bireysel bakımlarında aktif ve etkili olmalarının sağladığını, güçlendirme tabanlı eğitimin kronik hastalığı olan bireylerin normal hayat sürmelerinin bir yolu olduğunu belirtmişlerdir. Literatürde yapılan diğer benzer çalışmalarda da hasta güçlendirmenin sağlık çıktıları üzerinde olumlu değişiklikler meydana getirdiği görülmektedir (Bravo et al., 2015, Yeh et al., 2018, Camerini et al., 2012). Bu çalışmada yaşam kalitesi üzerinde etkisi olabileceğini düşündüğümüz yaş, cinsiyet ve hasta güçlendirme değişkenlerinin yaşam kalitesi üzerinde orta düzeyde etkisinin olduğu gözlemlenmiştir. Literatürdeki çalışmalar hasta güçlendirmenin yaşam kalitesi üzerinde olumlu değişiklikler meydana getirdiğini göstermektedir. Bu çalışmada ortaya çıkan orta düzeyde etkinin seçilen birçok kronik hastalığın bir arada incelenmesinden dolayı olabileceği düşünülmektedir.

Sonuç olarak hasta güçlendirmenin yaşam kalitesi üzerindeki etkisinin incelendiği bu çalışmada, literatürle paralel olarak aralarında ilişki olduğu (orta düzeyde), yaş ile hasta güçlendirme ve yaşam kalitesi arasında ters ilişki olduğu, cinsiyetin hasta güçlendirme ve yaşam kalitesi üzerinde etkili olmadığı, kronik hastalık türünün ise hem yaşam kalitesini hem de hasta güçlendirme üzerinde etkili olduğu sonucuna ulaşılmıştır. Bu sonuçlar doğrultusunda hasta güçlendirmenin yaşam kalitesini artırdı̆̆ 1 ve bu yüzden hasta güçlendirme çalışmalarının artırılması gerektiği, ileri yaşlarda düşen hasta güçlendirme skoruna yönelik çalışmaların yapılması, kronik hastalıklara hasta güçlendirme tekniklerinin uygulanmasının yaşam kalitesini artıracağı düşünülmektedir.

Sağlık okuryazarlığının ve hasta aktif katılımının kişinin algıladığı sağlık statüsüne pozitif katkıları göz önünde bulundurulduğunda bu unsurların hasta güçlendirme ve yaşam kalitesi üzerinde önemli etkilerinin 
olduğu görülmektedir. Bu nedenle özellikle de kronik hastalığa sahip belirli yaşın üzerindeki bireylerin kendi sağlık durumunu anlayabileceği ve hastalıklarına ilişkin şikâyetlerini ifade edebilecekleri şekilde güçlendirilmeleri, yaşam kalitesini düşürmeden başarılı şekilde yaşlanmalarına katkı sağlayacak eğitsel uygulama ve danışmanlıkların hayata geçirilmesi önerilmektedir. Hasta güçlendirme programlarının Hasta uygulanması hastayı kendi hastalığının yönetimi konusunda daha yetkin hale getirecek ve sağlık kuruluşlarına olan bağlılıklarını azaltmaya yardımcı olacaktır. Özellikle de kronik hastalıklarda bu durum hastanın kendini daha güvende ve öz kontrole sahip hissetmesini sağlayacaktır. Sağlik profesyonellerinin hastalarla kendi sağlıkları için paternalist yaklaşımdan vazgeçerek onlarla motive edici görüşmeler yapması hasta otonomisi üzerinde önemli katkılar ve daha yüksek hasta tatmini sağlayacaktır.

Makro düzeyde sağlık politikalarının amacı sadece hastaların sağlık hizmetlerine sadece erişimi kolaylaştıracak şekilde tasarlanması olmamalıdır. Aynı zamanda hastaların bu süreçlerin önemli bir parçası olmalarını sağlayacak şekilde düzenlenmesi, hastaların haklarını daha iyi bilmelerini sağlayacak, kendi durumlarıyla ilgili soru sormaya cesaretlendirecek, sağlık okuryazarlık düzeyini yükseltecek, hizmet sunan sağlık personelinin de empatik bir eğilimle hastayı anlaması ve süreçte daha etkin katılımını sağlayacak düzenlemelerin gerçekleştirilmesi faydalı olacaktır. $\mathrm{Bu}$ nedenle hasta-hekim iletişiminde hastanın bireysel tercihlerinin olası fayda ve riskleri hekim tarafından anlaşılır şekilde aktarılmalıdır. Ayrıca bundan sonra yapılacak çalışmalarda evrenin genişletilerek hasta sayılarının ve kronik hastalık sayısının artırılması konu hakkında geniş çaplı yorumlanabilir sonuçlar verebileceği düşünüldügünden dolayı konu üzerinde çalışacak araştırmacılara önerilmektedir.

\section{Kaynakça}

Alden, D. (2014). Associated with Patient Empowerment Prior to Cancer Treatment Decision Making, Medical Decision Making, 34(7): 884-98.

All Party Parliamentary Groups on Global Health; HIV/AIDS; Population Development and Reproductive Health; Global Tuberculosis; and Patientand Public Involvement in Health and Social Care. (2014). Patient Empowerment: for Better Quality, More Sustainable Health Services Globally.

Barr, PJ., Scholl. I., Bravo, P., Faber, MJ., Elwyn, G. ve McAllister, M. (2015). Assessment of Patient Empowerment-A Systematic Review of Measures, PLoS ONE 10(5): e0126553. doi:10.1371/journal.pone.0126553 
İşletme Bilimi Dergisi (JOBS), 2020; 8(1): 97-114. DOI: 10.22139/jobs.682555

Hasta

Güçlendirme ve Yaşam Kalitesi

İlişkisi

110
Boylu, A.A. ve Paçacıoğlu, B. (2016). Yaşam Kalitesi Göstergeleri, Journal of Academic Researches and Studies, 8(15):137-150.

Bravo, P., Edwars, A., Barr, P.J., Scholl, I., Elwyn, G. ve McAllister, M. (2015). Cochrane Health Care Quality Research Group, Conseptualising Patient Empowerment: A Mixed Methods Study, BMC Health Services Research, 15:252.

Camerini L., Schulz P. ve Nakamoto K. (2012). Differential Effects of Health Knowledge and Health Empowerment Over Patients' Self-Management and Health Outcomes: A Cross-Sectional Evaluation, Patient Education and Counseling, 89:337-344.

Çimen, Z. ve Temel, A. B. (2017). Kronik Hastalığı Olan Yaşlı Bireylerde Sağlık Okuryazarlığı ve Sağlık Algısı İlişkisi ve Sağlık Okuryazarlığını Etkileyen Faktörlerin İncelenmesi, Ege Üniversitesi Hemşirelik Fakültesi Dergisi, 33(3):105125.

Delespaul, P., Milo, M., Schalken, F., Boevink, W., Van Os, J., ve Goede, G.G.Z. (2016). Nieuwe Concepten, Aangepaste Taal, Verbeterde Organisatie. Diagnosis Uitgevers, Amsterdam.

Feste, C. ve Anderson, R.M. (1995). Empowerment: From Philosophy to Practice. Patient Educ Couns. 26(1-3):139-44.

Forlani, G., Zannoni, C., Tarrini, G., Melchionda, N. ve Marchesini, G. (2006). An Empowerment-Based Educational Program İmproves Psychological WellBeing and Health-Related Quality of Life in Type 1 Diabets, Journal of Endocrinological Investigation, 29:405-412.

Kaya, N. ve Işık, O. (2018). Hasta Güçlendirme Ölçeğinin Geçerlilik ve Güvenilirliği, İsletme Bilimi Dergisi (JOBS), 6(1):21-42. doi: 10.22139/jobs.403021.

McAllister, M., Dunn, G., Payne, K., Davies, L. ve Todd, C. (2012). Patient Empowerment: The Need to Consider It as A Measurable Patient-Reported Outcome for Chronic Conditions. BMC Health Services Research, 12:157.

Megari, K. (2013). Quality of Life in Chronic Disease Patients. Health Psychology Research, 1(3):1-20.

Náfrádi, L., Nkamoto, K., Csabai, M. ve Papp-Zipernovszky, O. (2018). An Empirical Test of the Health Empowerment Model: Does Patient Empowerment Moderate the Effect of Health Literacy on Health Status?, Patient Education and Counseling, 101:511-517.

Perkins, D. ve Zimmerman, M. (1995). Empowerment Theory, Research and Application, AmJ Community Psychol, 23(5):69-79.

Russo, G.,Tartaglione, A.M., ve Cavacece, Y. (2019). “Empowering Patients to CoCreate A Sustainable Healthcare Value, Sustainability 2019, 11, 1315; doi:10.3390/su11051315. www.mdpi.com/journal/sustainability. 
Raheb, G., Kazemi, S.V., Alipour, F., Hosseinzadeh, S. ve Teymouri, R. (2018). Effectiveness of Self-Care Training Program Based on Empowerment Model on Quality of Life among Hemodialysis Patients in the City of Sari, Iran. Middle East Journal of Family Medicine, 1;7(10):16.

Schulz, P.J. ve Nakamoto, K. (2011). “Bad” Literacy, The Internet, and The Limits of Patient Empowerment. In: AAAI Spring Symposium Series: Artificial Hasta Intelligence \& Health Communication, 65-69.

Small, N.L. (2012), Patient Empowerment in Long-Term Condition: Development and Validation of A New Measure. Unpublished Phd Thesis, Manchester, University of Manchester.

Small, N., Bower, P., Chew-Graham, C.A., Whalley, D. ve Protheroe, j. (2013). Patient empowerment in long-term conditions: development and preliminary testing of a new measure. BMC Health Serv Res 13, 263.https://doi.org/10.1186/14726963-13-263

Soyyiğit, Ş., Erk, M., Güler, N., ve Kılınç, G. (2006). Kronik Obstrüktif Akciğer Hastalığında Yaşam Kalitesinin Belirlenmesinde SF-36 Sağlık Taramasının Değeri, Tüberküloz ve Toraks Dergisi, 54(3):259-266.

Tabari, F., Pedram Razi, S.H., Asadi Gharabaghi, M., Torabi, S., Mehran, A., Mohamadinejad, F., Amini, F., Abbaszadeh, R. ve Rezaie Zivlaei, M. (2018). Effect of Education Based on Family-Centered Empowerment Model on The Quality of Life of Elderly Patients With Chronic Obstructive Pulmonary Disease (COPD). Medical Science, 22(91):301-311.

Teymori, F., Alhani, F. ve Kazemnejad, A. (2017). The Effect of Family-Centered Empowerment Model on Self-Efficacy and Self-Esteem of The Children Eith Asthma, Preventive Care in Nursing \& Midwifery Journal, 7(1): 18-26.

Tol, A.,Alhani, F., Shojaeazadeh, D., Sharifirad, G., ve Moazam, N. (2015). An Empowering Approach to Promote the Quality of Life and Self-Management among Type 2 Diabetic Patients. Journal of Education and Health Promotion, 4(13):1-27.

Wilson, I.B. ve Cleary, P.D. (1995). Linking Clinical Variables with Health-Related Quality of Life: A Conceptual Model of Patient Outcomes. J AmMedAssoc, 273:59-65.

World Health Organization, Regional Office for Europe. (2013) Health 2020 Policy Framework and Strategy Document; WHO: Geneva, Switzerland.

Yeh, M.Y., Wu. S.C. ve Tung, T.H. (2018). The Relation Between Patient Education, Patient Empowerment and Patient Satisfaction: A Cross-SectionalComparison Study, Applied Nursing Research, 39:11-17.

\section{THE RELATIONSHIP OF PATIENT EMPOWERMENT AND LIFE QUALITY}




\section{Hasta}

Güçlendirme ve Yaşam Kalitesi

İlişkisi

112

\section{EXTENDED ABSTRACT}

Throughout human history, all societies have worked on protecting human life, extending life expectancy and life expectancy at birth. These studies have led to improvements in areas such as healthy lifestyle, environmental health, and the fight against harmful substances, which are closely related to the subject, especially health services. As a result of all this, the average life expectancy and life expectancy at birth have increased in many societies worldwide, especially in the last century. While it is an desired status that the average life expectancy is increasing, it also brought some problems. The proportion of elderly population formed by the increase in the average life expectancy made studies specific to this area necessary. The provision of health services for the elderly is at the top of these studies. Another field of study is the care needs of individuals with chronic diseases that appear with increasing old age. Increasing the lifes time has led to an increase in chronic disease rates. Long-term care and continuous use of medicines require large financial resources in the management of chronic diseases. Countries searched differently for the financial burden of chronic diseases in health systems. It is stated that the best solution for these studies, whose main purpose is to provide sustainability in healthcare services, is patient-centered care and empowerment of patients to participate in treatment.

Patient empowerment can be explained as informing individuals about their diseases and treatments and enabling them to participate in their treatment. In order for the patient to participate in the treatment, person must have general health information (health information literacy), which is called health literacy, to access the information needed about health, to understand, evaluate and use this information to improve health. The second thing that needs to be done to ensure that the individual with health literacy is included in the treatment is to increase the level of knowledge about the disease, treatment type and healthy lifestyle with this disease. The first step of this stage is to have information about the disease that the person has. The individual who knows about the disease will know what the symptoms of the disease are and will be able to interpret the state of health. The second step of this stage is to have information about the treatment of the disease it has. An individual who is knowledgeable about the treatment of his disease will be able to contribute individually to the treatment as soon as he feels the symptoms of the disease. The third step of this phase is to provide a healthy 
lifestyle. In this step, it is ensured that the person can continue his life with the highest possible quality with the disease person has. It is stated that individuals who have sufficient knowledge about the disease and who can participate individually in treatment lead a better life quality compared to individuals who do not have this competence. Therefore, patient empowerment is expressed as the solution of the density and economic Hasta burden on health systems in the world. With patient empowerment, individuals will have information about their diseases, treatment modalities and diseases, and continuing their lives and will apply to health institutions when they really need it.

$\mathrm{n}$ this study, it was aimed to determine the relationship between patient empowerment and life quality and the factors affecting patients' life quality. For this purpose, a group of patients with chronic disease was interviewed to include them in the study. These patients were selected from patients who applied to a university hospital in February and March 2018. While determining the patients, applying to the outpatient clinic in the internal medicine, chest diseases, cardiology and general surgery units and being chronic patients were used as the criterion to include in the research. Patients with chronic disease, asthma, diabetes, chronic obstructive pulmonary disease (copd), patients with thyroid and heart disease were included in the study. The data of the research were collected with a questionnaire form. The questionnaire form consisting of three parts was applied to the individuals included in the research. The first part of the questionnaire includes descriptive features, chronic diseases and questions about the outpatient clinic they apply to. In the second part of the survey, there is a patient empowerment scale developed by Small (2012) and whose validity and reliability in Turkish was performed by Kaya and Işık (2018). The scale, which was originally composed of 47 expressions, was reduced to 37 expressions whose goodness of fit was acceptable as a result of the confirmatory factor analysis conducted by Kaya and Işık (2018). In the second part of the questionnaire, a 37 item scale was used. In the third part of the survey, the Dutch model of the EQ-5D 5L scale developed by The Euro Qol Group was used to measure the life quality of patients. This model consists of five dimensions and 25 expressions. The patients to be included in the study were selected by random sampling method. The first of the analyzes made using the data obtained was made for the relationship between patient empowerment and life quality. The relationship between patient empowerment and life quality was examined by Pearson correlation analysis. In the second analysis, the evaluation of patient empowerment and life quality scores in terms of age groups and type of chronic disease were 


\section{Hasta}

Güçlendirme ve Yaşam Kalitesi

İlişkisi

114 examined with the Duplex Manova analysis. In the third analysis, the relationship between patient empowerment and life quality scores and gender was examined with the independent sample $T$ test. Linear regression analysis was used to evaluate the factors that affect the life quality of the final analysis patients.

In this study, which was conducted to examine the relationship between patient empowerment and life quality in individuals with chronic disease and to determine the factors affecting life quality, patients obtained an average score of 130.18 from the patient empowerment scale. As a result of the analysis, a negative relationship was found between age, life quality and patient empowerment. The highest life quality and patient empowerment score by age groups appeared in the youngest group. In another analysis in which patient empowerment and life quality scores were examined by gender, it was concluded that patient empowerment and life quality scores did not differ by gender. Significant differences were found between patient empowerment and life quality score averages according to the type of chronic disease. While the disease group with the highest life quality is thyroid, COPD patients constitute the lowest group. The same results were obtained between patient empowerment and chronic diseases as well as life quality. Thyroid patients had the highest average in the patient empowerment score, and COPD patients had the lowest average. The groups that make the difference in patient empowerment are thyroid and COPD, whereas life quality is COPD and diabetes patients. In the correlation analysis conducted to examine the relationship between patient empowerment and life quality, there was no multiple correlation between the variables included in the model and there was a moderately positive correlation between them $(R=0,505 ; R 2=0,255$; Adjusted $R 2=0,251$ Durbin Watson $=1.592)$. In the regression model, it was concluded that patient empowerment, gender and age variables had a significant effect on life quality, and these three variables could explain $25 \%$ of the change in life quality together.

Considering the positive contributions of health literacy and patient active participation to the health status perceived by the person, these elements have important effects on patient empowerment and life quality. For this reason, it is recommended to strengthen individuals with a chronic disease over a certain age so that they can understand their own health status and express their complaints about their illnesses, and to implement educational practices and counseling that will contribute to their successful aging without reducing the life quality.

Key Words: Chronic Illness, Patient Empowerment, Life Quality 